\title{
The Effect of Rat Strain, Diet Composition and Feeding Period on the Development of a Nutritional Model of Non-Alcoholic Fatty Liver Disease in Rats
}

\author{
O. KUČERA ${ }^{1}$, T. GARNOL ${ }^{1}$, H. LOTKOVÁ ${ }^{1}$, P. STAŇKOVÁ $^{1}$, Y. MAZUROVÁ ${ }^{2}$, \\ M. HROCH ${ }^{3}$, R. BOLEHOVSKÁ ${ }^{1}$, T. ROUŠAR ${ }^{1}$, Z. ČERVINKOVÁ ${ }^{1}$
}

${ }^{1}$ Department of Physiology, Faculty of Medicine in Hradec Králové, Charles University in Prague, Hradec Králové, Czech Republic, ${ }^{2}$ Department of Histology and Embryology, Faculty of Medicine in Hradec Králové, Charles University in Prague, Hradec Králové, Czech Republic, ${ }^{3}$ Department of Pharmacology, Faculty of Medicine in Hradec Králové, Charles University in Prague, Hradec Králové, Czech Republic

Received April 26, 2010

Accepted August 19, 2010

On-line November 29, 2010

\section{Summary}

Non-alcoholic fatty liver disease (NAFLD) is an important cause of liver-related morbidity and mortality. The aim of this work was to establish and characterize a nutritional model of NAFLD in rats. Wistar or Sprague-Dawley male rats were fed ad libitum a standard diet (ST-1, $10 \% \mathrm{kcal}$ fat), a medium-fat gelled diet (MFGD, $35 \%$ kcal fat) and a high-fat gelled diet (HFGD, $71 \% \mathrm{kcal}$ fat) for 3 or 6 weeks. We examined the serum biochemistry, the hepatic malondialdehyde, reduced glutathione (GSH) and cytokine concentration, the respiration of liver mitochondria, the expression of uncoupling protein-2 (UCP-2) mRNA in the liver and histopathological samples. Feeding with MFGD and HFGD in Wistar rats or HFGD in Sprague-Dawley rats induced small-droplet or mixed steatosis without focal inflammation or necrosis. Compared to the standard diet, there were no significant differences in serum biochemical parameters, except lower concentrations of triacylglycerols in HFGD and MFGD groups. Liver GSH was decreased in rats fed HFGD for 3 weeks in comparison with ST-1. Higher hepatic malondialdehyde was found in both strains of rats fed HFGD for 6 weeks and in Sprague-Dawley groups using MFGD or HFGD for 3 weeks vs. the standard diet. Expression of UCP-2 mRNA was increased in Wistar rats fed MFGD and HFGD for 6 weeks and in Sprague-Dawley rats using HFGD for 6 weeks compared to ST-1. The present study showed that male Wistar and Sprague-Dawley rats fed by HFGD developed comparable simple steatosis without signs of progression to non-alcoholic steatohepatitis under our experimental conditions.

\section{Key words}

Fatty Liver • Oxidative stress • Cytokines

\section{Corresponding author}

O. Kučera, Faculty of Medicine in Hradec Králové, Charles University in Prague, PO BOX 38, Šimkova 870, Hradec Králové 1, 500 38, Czech Republic. Fax: +420495518772. E-mail: kucerao@lfhk.cuni.cz

\section{Introduction}

Non-alcoholic fatty liver disease (NAFLD) is the most common form of chronic liver disease in the Western world (Erickson 2009). The prognosis of NAFLD depends on the histological subtype of the disease. Primary NAFLD is considered the hepatic manifestation of the metabolic syndrome, whereas secondary NAFLD is a consequence of rapid weight loss, jejunoileal bypass, total parenteral nutrition, intestinal bacterial overgrowth or exposure to certain drugs and toxins (McClain et al. 2004).

The pathogenesis of NAFLD is not completely understood but two-hit (Day and James 1998) or multiplehit theories have been considered. In brief, accumulation of lipids in the liver is an essential condition for developing NAFLD. Fatty hepatocytes become more sensitive to other factors, such as oxidative stress (Grattagliano et al. 2008), 
mitochondrial dysfunction (Romestaing et al. 2008), cytokines and adipocytokines (Tilg 2010), and gut-derived lipopolysaccharide (Kirsch et al. 2006). These insults to hepatocytes may promote hepatocellular injury and liver inflammation.

Appropriate animal models of fatty liver are an essential tool for studying the mechanisms of NAFLD development and for testing potential drugs for NAFLD treatment. Such models should exert as much similarity to human NAFLD as possible. However, currently used models reflect human NAFLD only partially.

There are nutritional, drug-induced (Fernø et al. 2009), toxic, and genetic models (Forcheron et al. 2009) of NAFLD in rats. Nutritional models involve a high-fat diet, methionin cholin-deficient diet (MCDD) (Yoshioka et al. 2010), high saccharose, fructose (Kawasaki et al. 2009) and cholesterol diet (Jeong et al. 2005). Nutritional highfat animal models seem to simulate human pathogenesis of primary NAFLD most closely, though they lack some features of human NAFLD (esp. spontaneous progression to non-alcoholic steatohepatitis (NASH) and cirrhosis, natural multifactorial etiology).

There are many experimental designs for developing fatty liver or NASH in rats using high fat diets. Various protocols differ in terms of the period of feeding, nutritional definition of diets, age, strain and sex of rats, method of feeding, and others. High-fat diets vary in the percentage of energy provided in lipids from $42 \%$ (Buettner et al. 2006) up to $77 \%$ (Zou et al. 2006). Variation can also be found in the preference of the composition of polyunsaturated, monounsaturated or saturated fatty acids (Lieber et al. 2004, Buettner et al. 2006, Romestaing et al. 2007). Rats are fed a high-fat diet from 3 (Lieber et al. 2004) to 14 weeks (Romestaing et al. 2007) or longer. Nutritional models using high fat diets are successful in developing simple liver steatosis but not in progressing to NASH in rats (Ahmed et al. 2009), the Lieber model being the exception (Lieber et al. 2004).

The present study characterizes and compares the effect of a high-fat diet ( $71 \% \mathrm{kcal}$ fat) on two strains of rats and in two time intervals of feeding.

\section{Methods}

Male Wistar (BioTest, Czech Republic) and Sprague-Dawley rats (AnLab, Czech Republic) with initial weight of $250 \pm 30 \mathrm{~g}$ were used throughout the study. The rats were housed at $23 \pm 1{ }^{\circ} \mathrm{C}, 55 \pm 10 \%$ humidity, air exchange 12-14 times/h and $12 \mathrm{~h}$ light-dark cycle. The
Table 1. Definition of groups and number of animals in groups. ST-1 - standard diet, MFGD - medium-fat gelled diet, HFGD high-fat gelled diet.

\begin{tabular}{lccc}
\hline \multicolumn{1}{c}{ Strain } & Feeding & Groups & $\begin{array}{c}\text { Number of } \\
\text { animals }\end{array}$ \\
\hline Wistar & 3 weeks & ST-1 & 5 \\
& 3 weeks & MFGD & 5 \\
Sprague-Dawley & 3 weeks & HFGD & 5 \\
& 3 weeks & ST-1 & 6 \\
& 3 weeks & HFGD & 6 \\
Wistar & 6 weeks & ST-1 & 6 \\
& 6 weeks & MFGD & 7 \\
& 6 weeks & HFGD & 7 \\
Sprague-Dawley & 6 weeks & ST-1 & 6 \\
& & & $7(1$ died \\
& 6 weeks & MFGD & during the \\
& & & experiment $)$ \\
& 6 weeks & HFGD & 7 \\
\hline
\end{tabular}

animals had free access to tap water and different diets as described below. All the animals received care according to the guidelines set out by the Institutional Animal Use and Care Committee of Charles University in Prague and our study was approved by this committee.

The rats were divided into 12 groups (Table 1). Rats were fed a standard laboratory diet (ST-1, Velaz, Czech Republic; $10 \%$ kcal fat, $30 \%$ kcal proteins, $60 \%$ kcal saccharides), medium-fat gelled diet (MFGD; $35 \%$ kcal fat, $18 \%$ kcal proteins, $47 \%$ kcal saccharides; same composition as a standard liquid diet according to Lieber (Lieber et al. 2004)) or high-fat gelled diet (HFGD; $71 \%$ kcal fat, $18 \%$ kcal proteins, $11 \%$ kcal saccharides; Lieber et al. 2004) for 3 or 6 weeks. MFGD and HFGD diets were prepared from ingredients purchased from MP Biomedicals (Solon, OH). All chemicals, unless otherwise mentioned, were analytical grade and were obtained from Sigma-Aldrich Chemical Co. (St. Louis, MO). Mean weight gain, food and water intakes were monitored 3 times a week. After starvation for 14 hours, the animals were sacrificed and liver and serum samples were taken. Liver was stored on ice between procedures (weighing, mitotochondria isolation). Samples for consequent evaluation were immediately frozen in liquid nitrogen and stored at $-80^{\circ} \mathrm{C}$ until analysis.

\section{Serum biochemical measurements}

Serum glucose, total bilirubin, triglycerides, 
alanine aminotransferase (ALT), and aspartate aminotransferase (AST) activities were measured in the Institute for Clinical Biochemistry and Diagnostics, Faculty Hospital in Hradec Králové. Serum levels of interleukin-6 (IL-6) and transforming growth factor $\beta 1$ (TGF $\beta 1$ ) were analyzed using ELISA kits (Bender MedSystems, Austria).

\section{Measurement of oxygen uptake by isolated mitochondria}

Rat liver mitochondria were prepared from liver homogenates by conventional differential centrifugation (Schneider and Hogeboom 1950, Bustamante et al. 1977, Svátková et al. 1996). Oxygen consumption in isolated mitochondria was measured using High Resolution Oxygraph 2K (Oroboros, Austria). Measurements were performed in $2 \mathrm{ml}$ of potassium-medium at $30^{\circ} \mathrm{C}$ (Drahota et al. 2005). OROBOROS software (DatLab 3.1) was used to evaluate oxygen uptake.

\section{Determination of glutathione}

Liver homogenate was added into cold $10 \%$ metaphosphoric acid, shaken and centrifuged (20000 x g, $10 \mathrm{~min}, 4^{\circ} \mathrm{C}$ ). Glutathione in the supernatant was analyzed by modified fluorometric method (Hissin and Hilf 1976, Kand'ár et al. 2007). Briefly, reduced (GSH) and oxidized (GSSG) glutathione were allowed to react with ophthalaldehyde in phosphate buffer, and the fluorimetric detection was carried out $\left(\lambda_{\mathrm{Ex}}=350 \mathrm{~nm}, \lambda_{\mathrm{Em}}=420 \mathrm{~nm}\right)$.

\section{Determination of tissue proteins}

Protein content was determined by the method of Lowry (Lowry et al. 1951) using bovine serum albumin as a standard.

\section{Determination of tissue cytokines and malondialdehyde}

Liver samples were homogenized in RIPA buffer and centrifuged (10000 x g). Concentrations of liver IL-6 and TGF $\beta 1$ in the supernatant were measured by ELISA. Total tissue malondialdehyde (MDA) was analyzed using a slightly modified method of Pilz (Pilz et al. 2000, Popelova et al. 2008). Briefly, derivatization with 2,4dinitrophenylhydrazine was performed after an alkaline hydrolyzation, and subsequent reversed-phase highperformance liquid chromatography (Agilent, USA).

\section{UCP-2 mRNA expression}

The total liver RNA was extracted by RNA Blue (Top-Bio, Czech Republic). Real-time two-step PCR was used for mRNA absolute quantification using plasmid standards. First-strand cDNA synthesis was performed with total RNA, which were reversely transcribed using oligo(dT) primer (Generi-Biotech, Czech Republic) and M-MLV reverse transcriptase (Top-Bio). ABI Prism 7900HT technology and TaqMan Universal Master Mix (Applied Biosystems, USA) were used to amplify cDNA. The specific UCP-2 primers and hydrolysis probe were designed by Generi-Biotech - forward primer 5'AAGACCATTGCACGAGAGGA3', reverse primer 5'GCAAGGGAGGTCGTCTGTC3' and probe 5'CCCAATGTTGCCCGAAATGCC3' labelled with FAM BHQ. For normalization, surfeit 1 gene (GeneriBiotech) was utilized.

\section{Liver histology}

Liver specimens were taken immediately after the rats were sacrificed and fixed by immersion in $4 \%$ neutral formaldehyde. Paraffin sections were stained with hematoxylin-eosin to detect hepatic steatosis, inflammation and necrosis. Formaldehyde-fixed frozen sections stained with Sudan 3 were used for lipid detection. Fatty degeneration was graded according to the percentage of fat-containing hepatocytes - grade 1:0-25\%; grade 2:26-50\%; grade 3:51-75\%; grade 4:76-100\%. A degree of the inflammatory reaction and necrosis was indicated as the average counted in 10 randomly selected fields in each slide. Three-point scale was used for classification of these changes $-0=$ normal; $1=$ mild; $2=$ moderate; $3=$ severe (Avni et al. 2004).

Determination of tissue triacylglycerols (TAG) and cholesterol

Lipids from rat livers were prepared using chloroform-methanol extraction (Bligh and Dyer 1959). Total cholesterol and TAG were measured using commercial kits (Roche, Germany).

\section{Statistical analysis}

The results are expressed as the mean \pm S.D. Comparisons were made among the groups using ANOVA followed by Tukey-Kramer's post test (GraphPad Prism 4.03, GraphPad Software, CA) at the selected level of significance of $\mathrm{P}<0.05$.

\section{Results}

\section{Food intake, initial and final weight}

The average food intake is shown in Table 2. Wistar rats fed with ST-1 diet consumed a significantly 
higher amount of chow than the Sprague-Dawley strain. There was an increase in food intake in Sprague-Dawley rats fed with MFGD and HFGD for 3 weeks and HFGD for 6 weeks. There were no significant differences among Wistar rats fed by various types of diets.

There were no differences among groups of the same strain and time of feeding in the initial and final weights except for a lower final weight in SpragueDawley rats after 6 weeks of feeding with MFGD.

Liver weight, relative liver weight, liver triglycerides and cholesterol (Table 2)

The absolute liver weight of the same strain and of period of feeding was higher only in the MFGD in comparison to the ST-1 group in Sprague-Dawley rats fed for 3 weeks. The relative liver weight was significantly higher in MFGD and HFGD groups of Sprague-Dawley rats fed for 3 weeks. Absolute and relative liver weights were lower in Sprague-Dawley rats compared to Wistar rats. Liver tissue triglycerides and cholesterol were higher in MFGD and HFGD in both strains and periods of feeding. The highest triglycerides contents were found in HFGD after 6 weeks in Wistar and Sprague-Dawley rats.

\section{Serum characteristic (Table 2)}

Feeding with MFGD or HFGD did not cause any significant changes in the serum activities of ALT and AST. There were no differences among serum glycemia or total cholesterol within groups; glycemia of Sprague-Dawley rats fed ST-1 was lower than the glycemia of Wistar rats fed the same kind of diet $(p<0.05)$. Surprisingly, MFGD and HFGD caused a drop in serum triglycerides in all groups against ST-1. There were significantly lower levels of triglycerides in Sprague-Dawley rats in comparison with Wistar rat in both time periods.

\section{Liver content of GSH and total MDA (Table 2)}

A decrease in liver tissue GSH was found in Wistar rats fed HFGD for 3 weeks and Sprague-Dawley rats fed HFGD and MFGD for 3 weeks. There were no changes in GSH among rats within groups after 6 weeks. There was a significant increase in the total amount of MDA in the livers of Wistar rats fed HFGD for 6 weeks and Sprague-Dawley rats fed MFGD and HFGD for 3 weeks and HFGD for 6 weeks.
Liver and serum cytokines (Table 2)

Feeding with diets containing a higher percentage of fats increased liver IL-6, and significant changes were observed in HFGD in Wistar and Sprague-Dawley rats after 3 weeks and MFGD in Wistar rats after 6 weeks. Neither MFGD nor HFGD caused changes in tissue TGF $\beta 1$. Serum IL-6 and TGF $\beta 1$ levels were below detection limits of the kits.

\section{Activity of respiratory complexes I and II (Fig. 1)}

A significant decrease in the activity of respiratory complex I was found in Sprague-Dawley rats fed by HFGD for 3 weeks compared to ST-1 $(\mathrm{p}<0.05)$. There was a tendency of complex I to be lowered also in Sprague-Dawley and Wistar rats fed by MFGD, and MFGD or HFGD, resp. for 3 weeks, and in SpragueDawley rats fed by MFGD and HFGD for 6 week, but these changes were not significant.

\section{UCP-2 mRNA expression (Fig. 2)}

Increased expression of UCP-2 mRNA was observed in Sprague-Dawley and Wistar rats fed HFGD, and MFGD and HFGD, respectively, for 6 weeks.

\section{Histology of the liver tissue (Table 3, Fig. 3a-3f)}

In the liver tissue taken from control group of rats fed a standard diet (Fig. 3a, 3b), no signs of steatosis, inflammatory infiltrate or fibrosis were observed. There were no differences between ST-1 groups. Livers from Wistar rats fed MFGD for 3 or 6 weeks exhibited microvesicular steatosis without marks of inflammation or hepatocyte necrosis (Fig. 3c). However, MFGD did not induce significant steatosis in Sprague-Dawley rats (Fig. 3d). Livers from rats fed HFGD for 3 weeks displayed microvesicular steatosis without signs of progression to steatohepatitis in both strains. Microvesicular or mixed steatosis was not accompanied by inflammatory infiltrate, hepatocyte necrosis or fibrosis in the 6-week feeding period with HFGD in Wistar (Fig. 3e) and Sprague-Dalwey (Fig. 3f) rats.

\section{Discussion}

High-fat diets have been used to model obesity, liver steatosis, dyslipidemia etc. in rats for many years. Since the discovery of NAFLD, high-fat diets in rodents have been used in an attempt to reproduce human NAFLD. 


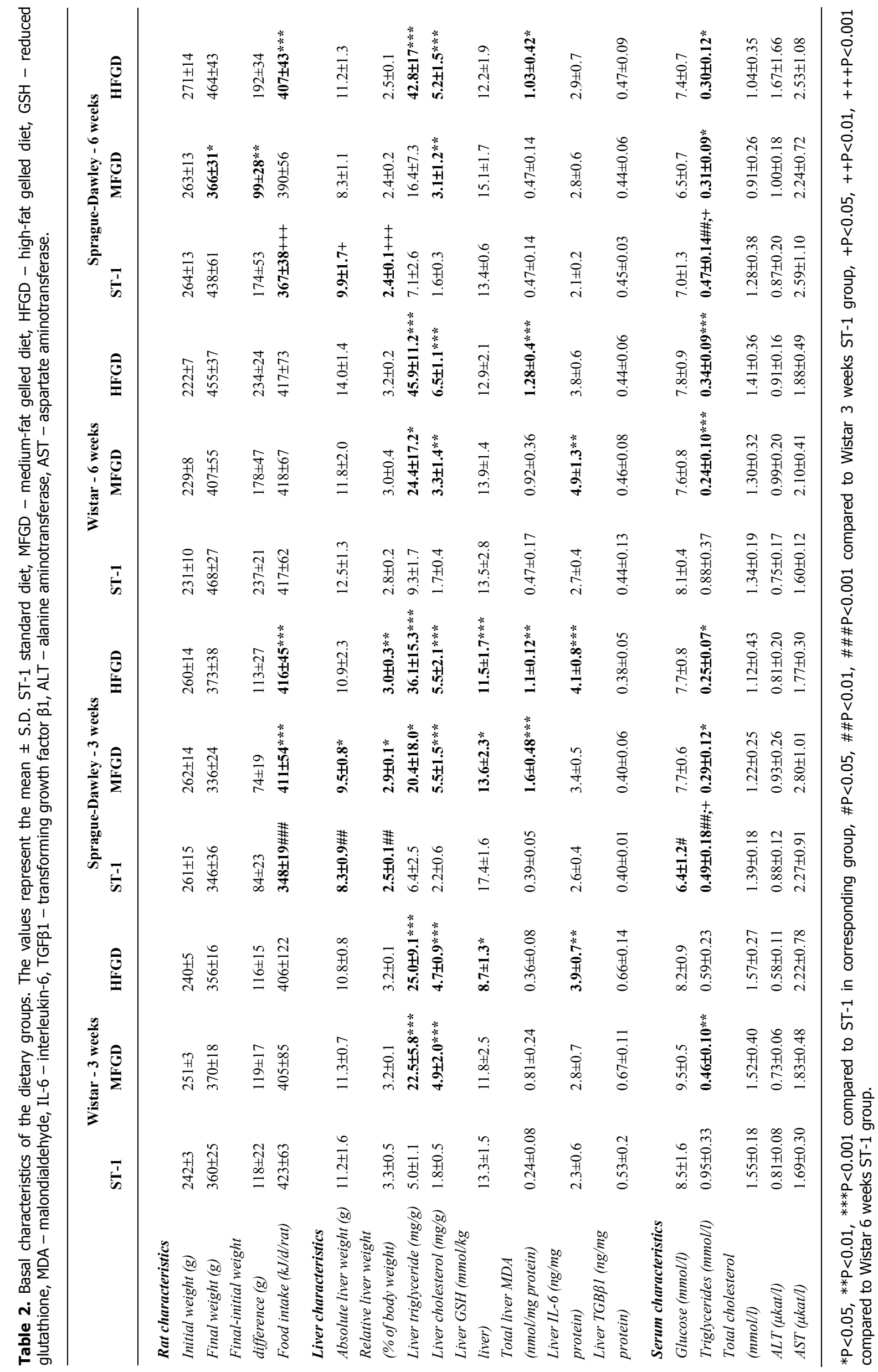




\section{Activity of respiratory complexes I and II}

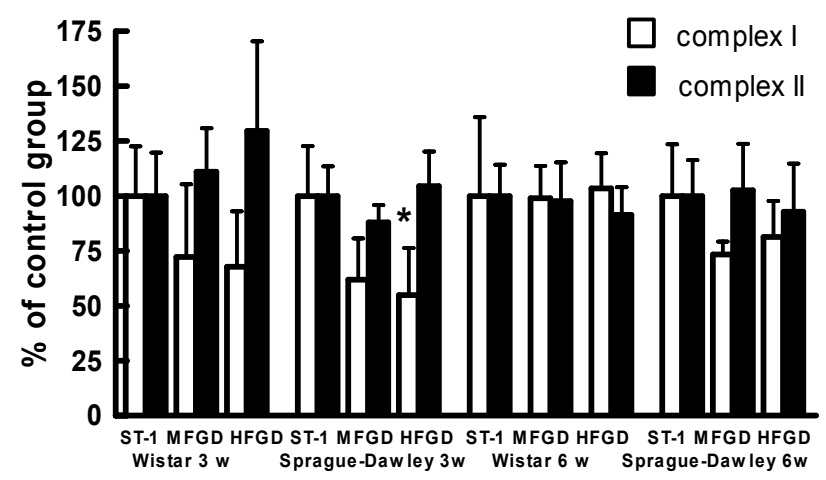

Fig. 1. Effect of feeding with MFGD and HFGD on the activity of respiratory complexes I and II. ST-1 - standard diet, MFGD medium-fat gelled diet, HFGD - high-fat gelled diet. * $p<0.05$ vs. ST-1 in Sprague-Dawley rats fed for 3 weeks.

Rodent animal models of NAFLD are essential tools for studying the mechanisms of NAFLD development. Currently, there is no animal model of NAFLD reflecting fully the histological and multifactorial pathophysiological characteristics of human NASH (Nanji 2004, London and George 2007). The present study has compared the time of feeding and strain differences in medium and high-fat nutritional models of NAFLD. Our nutritional models did not reproduce the liver changes typical of NASH. Feeding Wistar or Sprague-Dawley strains with HFGD for 3 or even 6 weeks caused simple microvesicular or mixed steatosis without inflammatory reaction or fibrosis. In contrast, Lieber et al. (2004), who used the same type of high-fat diet for only 3 weeks in Sprague-Dawley rats, reproduced typical hepatic lesions of human NASH. We did not induce significant inflammation or fibrosis even when Sprague-Dawley rats were fed HFGD for 6 weeks. The absence of severe inflammation and fibrosis in our experiment is confirmed by only slightly increased levels of liver IL-6 and similar hepatic content of TGF $\beta 1$ within the groups. Severe liver steatosis accompanied by inflammation has been regularly found in MCDD (Romestaing et al. 2007) but not characteristically in high-fat diet models, where either simple microvesicular or macrovesicular steatosis has been present (Buettner et al. 2006, Romestaing et al. 2007). Nevertheless, MCDD, which is quite often used as a model for the study of $\mathrm{NASH}$, does not follow the natural course of the disease. Steatohepatitis in MCDD is the consequence of the accumulation of TAG in the liver, reduced synthesis of glutathione and impaired liver formation of VLDL. Moreover, MCDD leads to severe weight loss and cachexia, which are not typical symptoms for human

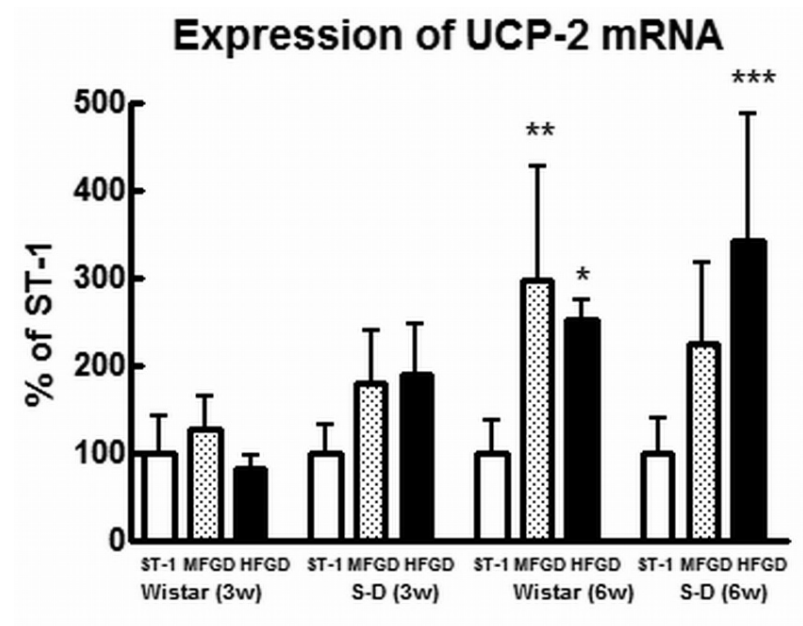

Fig. 2. Effect of feeding with MFGD and HFGD on the expression of UCP-2 mRNA. S-D Sprague-Dawley rats. UCP-2 - uncoupling protein-2, ST-1 - standard diet, MFGD - medium-fat gelled diet, HFGD - high-fat gelled diet. $*, * *$, and $* * * \mathrm{p}<0.05 ; 0.01$, and 0.001 , resp. vs. ST-1 in appropriate group.

\section{NASH (Romestaing et al. 2007).}

Lieber et al. (2004) used MFGD (35\% kcal fat) diet as a standard diet. However, standard diets for laboratory rats, as recommended by the American Institute of Nutrition, normally contain only about $10 \%$ of energy provided by fats (Reeves et al. 1993), while 30 to $35 \% \mathrm{kcal}$ fats is recommended for human beings. Feeding MFGD for 3 or 6 weeks induced significant microvesicular steatosis in Wistar rats but not in SpragueDawley rats. Wistar rats seem to be more sensitive to developing steatosis when consuming diets with a higher fat content in comparison with Sprague-Dawley rats. Our findings of the inability of MFGD to induce fatty liver changes in Sprague-Dawley rats are consistent with findings of other studies (Lieber et al. 2004, Ahmed et al. 2009).

Although Sprague-Dawley rats fed with MFGD and HFGD for 3 weeks and HFGD for 6 weeks had significantly higher food intake in comparison with the ST-1 group, we did not observe increase in final body weight. This could be related to the ability in particularly young rats to increase energy expenditure through increased production of heat (Berry et al. 1985). UCP-2 is a protein located in the inner mitochondrial membrane. UCP-2 causes the uncoupling of substrate oxidation in mitochondria from ATP formation. This is done by dissipating proton gradients and converting fuel to heat. Increased heat production occurs also in brown adipose tissue and skeletal muscles, where raised UCP-1 and UCP-3 expression and activation can be found after intake of foods rich in fats (Turner et al. 2007). The liver 
Table 3. Average histological grades of steatosis, inflammatory infiltrate, and necrosis of hepatocytes. ST-1 - standard diet, MFGD medium-fat gelled diet, HFGD - high-fat gelled diet.

\begin{tabular}{|c|c|c|c|c|c|c|c|c|c|c|c|c|}
\hline & \multicolumn{3}{|c|}{ Wistar -3 weeks } & \multicolumn{3}{|c|}{ Sprague-Dawley - 3 weeks } & \multicolumn{3}{|c|}{ Wistar -6 weeks } & \multicolumn{3}{|c|}{ Sprague-Dawley - 6 weeks } \\
\hline & ST-1 & MFGD & HFGD & ST-1 & MFGD & HFGD & ST-1 & MFGD & HFGD & ST-1 & MFGD & HFGD \\
\hline Steatosis & 1.0 & $3.3 \pm 0.5 * * *$ & $3.3 \pm 0.8 * * *$ & $1.0 \pm 0$ & $1.6 \pm 0.7 \times x x$ & $2.4 \pm 1.1 *$ & $1.0 \pm 0$ & $2.9 \pm 0.9 * * *$ & $3.1 \pm 0.8^{* * *}$ & $1.0 \pm 0$ & $1.4 \pm 0.5 \& \&$ & $2.9 \pm 0.7 * * *$ \\
\hline Inflammat & & & & & & & & & & & & \\
\hline infiltate & 0 & 0 & 0 & 0 & 0 & 0 & 0 & 0 & 0 & 0 & 0 & $0.1 \pm 0.4$ \\
\hline Necrosis & 0 & 0 & 0 & 0 & 0 & 0 & 0 & 0 & 0 & 0 & 0 & 0 \\
\hline
\end{tabular}

$* \mathrm{P}<0.05$, $* * * \mathrm{P}<0.001$ compared to $\mathrm{ST}-1$ in appropriate group, $\mathrm{xxx} \mathrm{P}<0.001$ compared to Wistar 3 weeks MFGD group, \&\&P<0.01 compared to Wistar 6 weeks MFGD group.

is the main organ involved in fatty acid metabolism, and fatty acids are implicated in the regulation of gene transcription in the liver (Pégorier et al. 2004). Saturated and monounsaturated fatty acids induce expression of lipogenetic genes in the liver, while the effect on the expression of genes involved in fat oxidation is various (Buettner et al. 2006). A polyunsaturated fatty acid-rich (PUFA) diet increases transcription of genes related to lipid oxidation (Buettner et al. 2006). PUFA activates fatty acid oxidation via the PPAR $\alpha$ (peroxisome proliferator-activated receptor $\alpha$ ) pathway more strongly than saturated or monounsaturated fatty acids (Duplus et al. 2000). UCP-2 expression in the liver is also regulated via PPAR $\alpha$, which is implicated as a regulator of lipid metabolism and energy homeostasis.

The decrease in serum TAG is not typical for patients suffering from NAFLD or in other nutritional animal models of NAFLD (Buettner et al. 2006), where serum neutral lipids are usually elevated. In explanation of lower serum TAG levels in MFGD and HFGD groups, we should take into account that samples were taken after 14 hours of starvation. Decrease in serum TAG can be caused principally by blockage of VLDL (very low density lipoprotein) secretion in the liver, the main lipoprotein transporting TAG in the plasma of fasting animals, and by elevated clearance of TAG by peripheral tissues. Secretion of VLDL in the liver is dependent on production of Apolipoprotein B-100 (Apo B-100) and availability of microsomal triglyceride transfer protein (MPT). Feeding with diet containing higher amount of fat leads to the development of insulin resistance. Changes in insulin sensitivity of peripheral tissues (skeletal muscles) and plasma hyperinsulinemia precede manifestation of other aspects of metabolic syndrome (Barnard et al. 1998). Acute hyperinsulinemia attenuates Apo B-100 synthesis in the liver (Cummings et al. 1995). MTP catalyzes the transfer of TAG to Apo B-100 and thus has a pivotal role in the assembly of VLDL. Insulin is known to inhibit MTP expression in the liver (Allister et al. 2005). High-fat feeding of rats is associated with metabolic adaptation of skeletal muscles for more efficient lipid uptake which leads to the accumulation of intramuscular lipids with a determinantal effect on insulin action and the development of peripheral insulin resistance (Hegarty et al. 2002). Nevertheless, further experiments are required to clarify the drop in serum TAG after MFGD and HFGD in rats. The activities of serum ALT and AST of rats fed MFGD or HFGD are within the physiological ranges which are commonly found in patients suffering from liver steatosis.

Higher levels of oxidative stress in the liver are found in animal models of NAFLD (Lieber et al. 2004, Nanji 2004). Oxidative stress is a result of increased hepatic fat load, decreased content of antioxidants, reduced activities of enzymes involved in the metabolism of reactive oxygen species (ROS), raised proinflammatory cytokines, activation of Kupffer cells, and mitochondrial dysfunction etc (Malaguarnera et al. 2009).

Redox changes in the fatty liver can be monitored by reduced glutathione content, or by changes in the ratio of GSH and GSSG. Intracellular glutathione seems to play an important role not only in scavenging ROS, but also in regulating gene expression (Franco et al. 2007) and in fibrogenic processes (Zheng et al. 2007). We found a decrease in liver tissue GSH levels in HFGD after 3 weeks in both strains, but these temporary changes were not observed after 6 weeks. This could be a consequence of metabolic adaptations of the liver to longer feeding with excessive fat. Lipid peroxidation, evaluated in our experiment by the hepatic content of MDA, can directly damage hepatocytes as well as increase 
,

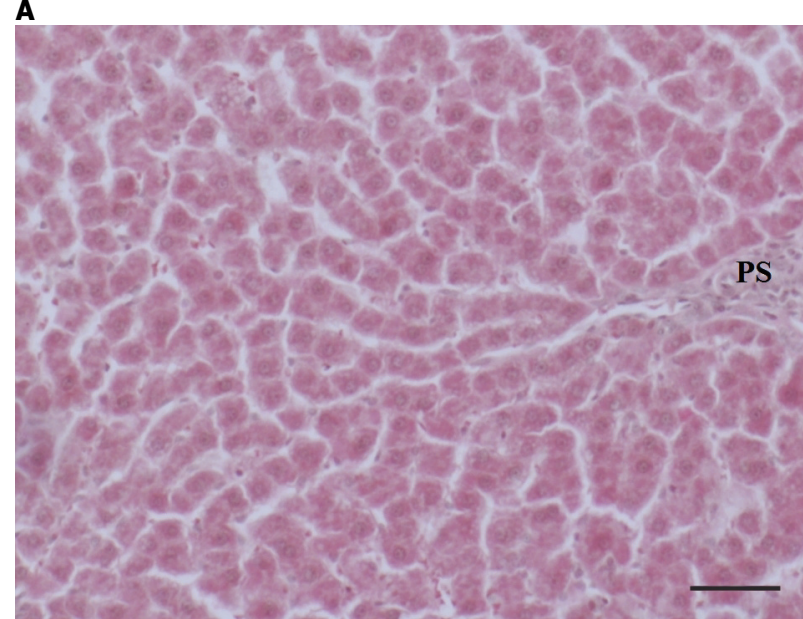

C

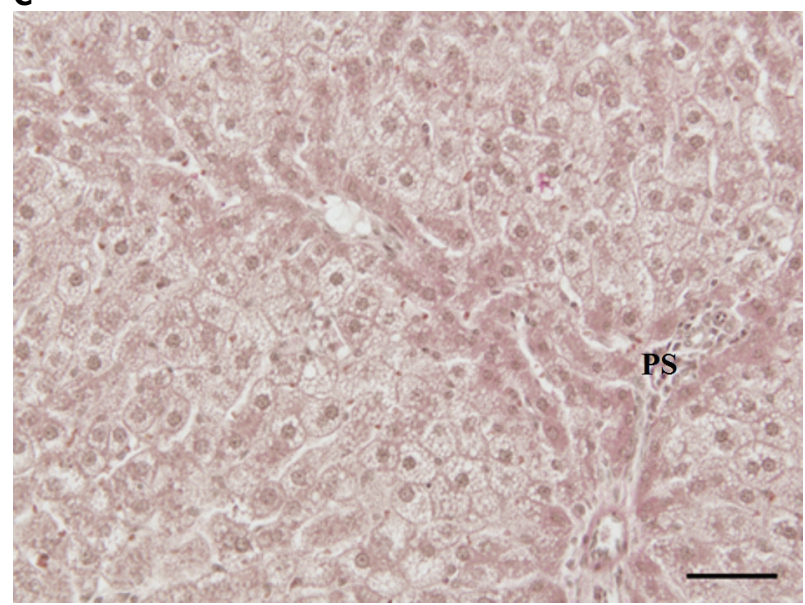

E

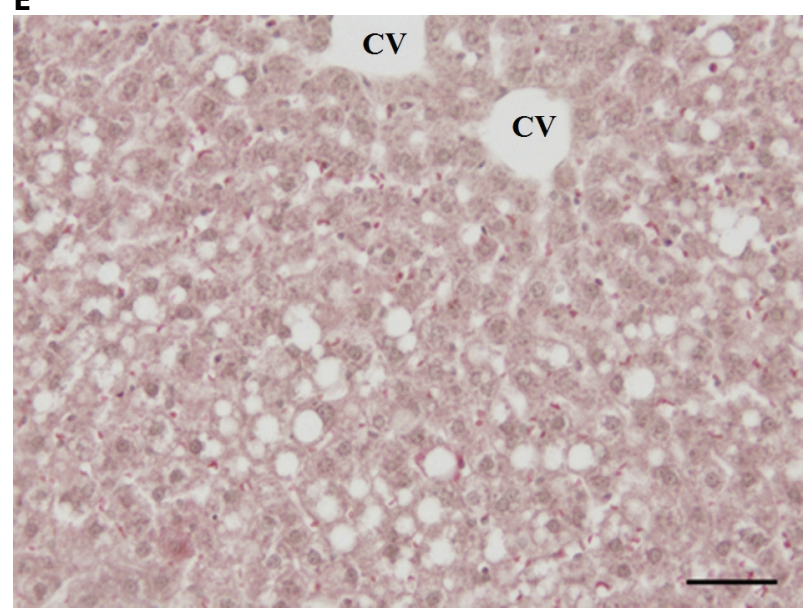

B

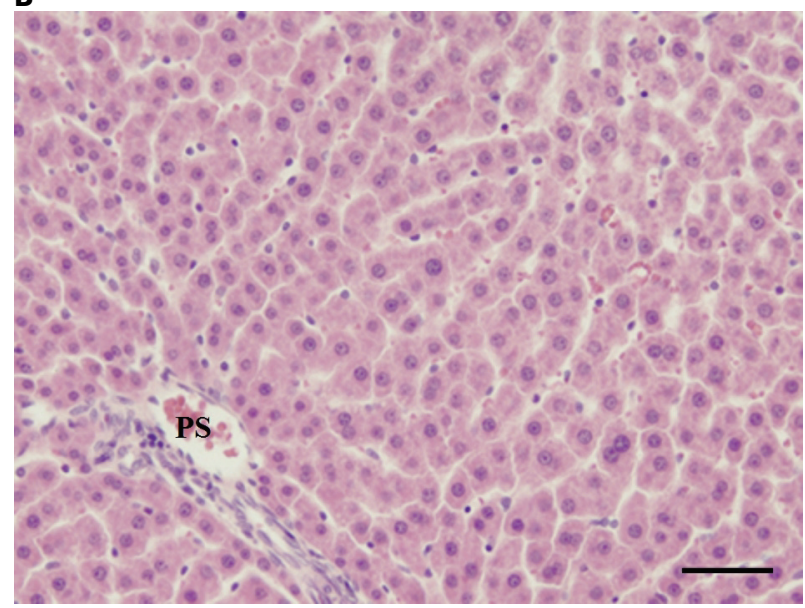

D

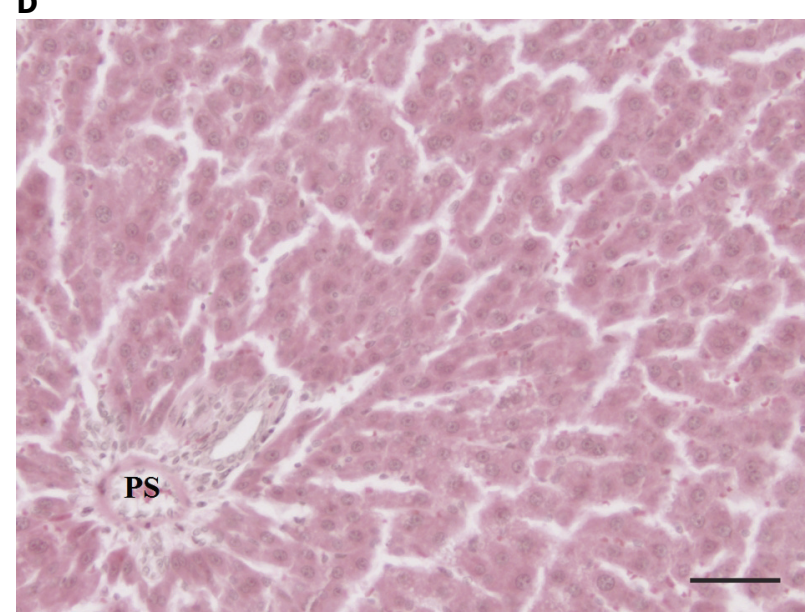

F

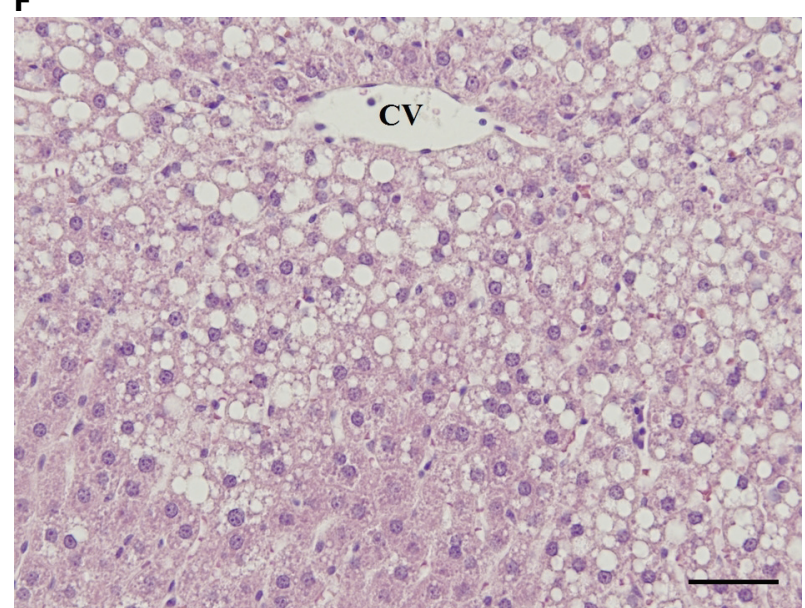

Fig. 3a-3f. Liver tissue taken from Wistar (Fig. 3a) and Sprague-Dawley (Fig. 3b) rats fed ST-1 for 6 weeks. Wistar rats fed MFGD for 6 weeks (Fig. 3c); Sprague-Dawley rats fed MFGD for 6 weeks (Fig. 3d); Wistar rats fed HFGD for 6 weeks (Fig. 3e) and SpragueDawley rats fed HFGD for 6 weeks (Fig. 3f). Fig. 3a and 3b - normal hepatocytes in a liver lobule; Fig. 3c - microvesicular steatosis affecting almost all hepatocytes without presence of inflammatory cells; Fig. 3d - insignificant microvesicular steatosis, only scatter hepatocytes are affected; Fig. $3 \mathrm{e}-$ focal mixed steatosis (here typical example of macrovesicular one) without inflammatory or fibrotic reaction; Fig. $3 \mathrm{f}$ - similar extent and character of steatosis developed primarily in the centrilobural region. CV - central vein, PS periportal space, ST-1 - standard diet, MFGD - medium-fat gelled diet, HFGD - high-fat gelled diet. Hematoxylin and eosin. Bar $50 \mu \mathrm{m}$.

hepatic inflammation (Lee et al. 2007) and can mediate fibrogenesis (George et al. 2003). Increased production of MDA does not correlate well with changes in liver glutathione. Changes in hepatic MDA correlate better with tissue TAG, cholesterol, and IL-6. Liver steatosis could affect lipid composition and fluidity of mitochondrial 
membranes (Ghoshal and Farber 1993) and enhance generation of lipoperoxidation products. Extra loads of fatty acids also raise fatty acid oxidation by less efficient peroxisomal pathways (Akbiyik et al. 2004), which can further increase the oxidative stress in the liver.

Accumulating evidence indicates that hepatic mitochondrial dysfunction is crucial to the pathogenesis of NAFLD (Vendemiale et al. 2001). ROS may be produced by electron leakage through complex I-III (Sato 2007). Free radicals mediate mitochondrial damage and mitochondrial dysfunction leads to higher production of free radicals (Feillet-Coudray et al. 2009). ROS can cause oxidative lesions in mtDNA (mitochondrial DNA) and may deplete mtDNA (Gao et al. 2004) which may decrease the synthesis of mtDNA-encoded respiratory chain polypeptides of complexes I, III, IV, and V, thus further blocking electron flow in the respiratory chain, and further increasing mitochondrial ROS formation (Pessayre 2007).

We observed a significant decrease in the activity of respiratory complex I in Sprague-Dawley rats fed HFGD for 3 weeks. Similar results of reduced activity of complex I were found in ob/ob mice (Garcia-Ruiz et al. 2006). More pronounced changes in respiratory complex I rather than in complex II in NAFLD can be explained by the higher sensitivity of complex I to oxidative stress (Drahota et al. 2005) and by depletion of mtDNA. Impairment of the $\mathrm{F}_{0} \mathrm{~F}_{1}$-ATP synthase complex found in steatotic livers can lead to reduced ATP levels and can be related to the oxidative stress occurring in the mitochondria isolated from fatty liver (Vendemiale et al. 2001). Increased production of ROS by mitochondria depletes hepatic GSH. We discovered lowering of liver GSH after 3 weeks of feeding with diet containing higher amount of fat, but not after 6 weeks. Changes in GSH correlate well with alterations of expression of UCP-2. The up-regulation of UCP-2 is thought to act as a protective mechanism against elevated mitochondrial formation of ROS (i.e. superoxide anion radical) by diminishing the redox pressure on the mitochondrial electron transport, but exposes the liver to chronic depletion of ATP (Serviddio et al. 2008) by decreasing the efficiency of energy synthesis. Moreover, mild increase in formation of lipoperoxidation products may induce mitochondrial uncoupling and thus prevent further lipid peroxidation (Echtay et al. 2003).
In conclusion, the present study showed that male Wistar and Sprague-Dawley rats developed comparable steatosis without signs of inflammation, necrosis, or fibrosis after 3 or 6 weeks of HFGD feeding. Other markers evaluated, such as liver tissue content of TAG, cholesterol, reduced glutathione, IL-6, and TGF $\beta 1$, were also similar in both strains. These rat nutritional models of NAFLD did not reproduce the typical liver lesions of human NASH in the Wistar or SpragueDawley strain of rats. The absence of progression of simple steatosis to NASH and the lacking of multifactorial etiology are the main disadvantages of most animal models of NAFLD. Spontaneous development of steatohepatitis does not occur in nutritional and metabolic models of steatosis (Farrel 2005). Nevertheless; animal models of NAFLD are useful for understanding the etiology, pathophysiology, and natural course of the disease as well as for assessing therapeutical approaches to treating human non-alcoholic fatty liver disease.

\section{Conflict of Interest}

There is no conflict of interest.

\section{Acknowledgements}

This study was supported by Grants GACR305/08/P184, GAUK126109, and MSM0021620820. The authors would like to thank Matthew Shane Renfro for the proofreading of this manuscript.

\section{Abreviations}

ALT - alanine aminotransferase, Apo B-100 Apolipoprotein B-100, AST - aspartate aminotransferase, $\mathrm{CV}$ - central vein, GSH - reduced glutathione, GSSG oxidized glutathione, HFGD - high-fat gelled diet, IL-6 interleukin-6, MCDD - methionin cholin-deficient diet, MDA - malondialdehyde, MFGD - medium-fat gelled diet, MPT - microsomal triglyceride transfer protein, mtDNA - mitochondrial DNA, NAFLD - non-alcoholic fatty liver disease, NASH - non-alcoholic steatohepatitis, PPAR $\alpha$ - peroxisome proliferator-activated receptor $\alpha$, PS - periportal space, PUFA - polyunsaturated fatty acid, ROS - reactive oxygen species, ST-1 - standard diet, TAG - triacylglycerols, TGF $\beta 1$ - transforming growth factor $\beta 1$, UCP-2 - uncoupling protein-2. 


\section{References}

AHMED U, REDGRAVE TG, OATES PS: Effect of dietary fat to produce non-alcoholic fatty liver in the rat. J Gastroenterol Hepatol 24: 1463-1471, 2009.

AKBIYIK F, CINAR K, DEMIRPENCE E, OZSULLU T, TUNCA R, HAZIROGLU R, YURDAYDIN C, UZUNALIMOGLU O, BOZKAYA H: Ligand-induced expression of peroxisome proliferator-activated receptor alpha and activation of fatty acid oxidation enzymes in fatty liver. Eur J Clin Invest 34: 429-435, 2004.

ALLISTER EM, BORRADAILE NM, EDWARDS JY, HUFF MW: Inhibition of microsomal triglyceride transfer protein expression and apolipoprotein B100 secretion by the citrus flavonoid naringenin and by insulin involves activation of the mitogen-activated protein kinase pathway in hepatocytes. Diabetes 54: 1676-1683, 2005.

AVNI Y, SHIRIN H, AEED H, SHAHMUROV M, BIRKENFELD S, BRUCK R: Thioacetamide-induced hepatic damage in a rat nutritional model of steatohepatitis. Hepatol Res 30: 141-147, 2004.

BARNARD RJ, ROBERTS CK, VARON SM, BERGER JJ: Diet-induced insulin resistance precedes other aspects of the metabolic syndrome. $J$ Appl Physiol 84: 1311-1315, 1998.

BERRY MN, CLARK DG, GRIVELL AR, WALLACE PG: The contribution of hepatic metabolism to diet-induced thermogenesis. Metabolism 34: 141-147, 1985.

BLIGH EG, DYER WJ: A rapid method of total lipid extraction and purification. Can J Biochem Physiol 37: 911-917, 1959.

BUETTNER R, PARHOFER KG, WOENCKHAUS M, WREDE CE, KUNZ-SCHUGHART LA, SCHÖLMERICH J, BOLLHEIMER LC: Defining high-fat-diet rat models: metabolic and molecular effects of different fat types. J Mol Endocrinol 36: 485-501, 2006.

BUSTAMANTE E, SOPER JW, PEDERSEN PL: A high-yield preparative method for isolation of rat liver mitochondria. Anal Biochem 80: 401-408, 1977.

CUMMINGS MH, WATTS GF, UMPLEBY AM, HENNESSY TR, KELLY JM, JACKSON NC, SÖNKSEN PH: Acute hyperinsulinemia decreases the hepatic secretion of very-low-density lipoprotein apolipoprotein B-100 in NIDDM. Diabetes 44: 1059-1065, 1995.

DAY CP, JAMES OF: Steatohepatitis: a tale of two "hits"? Gastroenterology 114: 842-845, 1998.

DRAHOTA Z, KŘIVÁKOVÁ P, ČERVINKOVÁ Z, KMONÍČKOVÁ E, LOTKOVÁ H, KUČERA O, HOUŠTEK J: Tert-butyl hydroperoxide selectively inhibits mitochondrial respiratory-chain enzymes in isolated rat hepatocytes. Physiol Res 54: 67-72, 2005.

DUPLUS E, GLORIAN M, FOREST C: Fatty acid regulation of gene transcription. $J$ Biol Chem 275: 30749-30752, 2000.

ECHTAY KS, ESTEVES TC, PAKAY JL, JEKABSONS MB, LAMBERT AJ, PORTERO-OTÍN M, PAMPLONA R, VIDAL-PUIG AJ, WANG S, ROEBUCK SJ, BRAND MD: A signalling role for 4-hydroxy-2-nonenal in regulation of mitochondrial uncoupling. EMBO J 22: 4103-4110, 2003.

ERICKSON SK: Nonalcoholic fatty liver disease. J Lipid Res $\mathbf{5 0}$ (Suppl): S412-S416, 2009.

FARRELL GC: Animal models of steatohepatitis. In: Fatty Liver Disease: NASH and Related Disorders. GC FARRELL, J GEORGE, De LA M HALL P, MC CULLOUGH AJ (eds), Backwell Publishing, Malden, MA, 2005, pp 91-108.

FEILLET-COUDRAY C, SUTRA T, FOURET G, RAMOS J, WRUTNIAK-CABELLO C, CABELLO G, CRISTOL JP, COUDRAY C: Oxidative stress in rats fed a high-fat high-sucrose diet and preventive effect of polyphenols: Involvement of mitochondrial and NAD(P)H oxidase systems. Free Radic Biol Med 46: 624-632, 2009.

FERNØ J, VIK-MO AO, JASSIM G, HÅVIK B, BERGE K, SKREDE S, GUDBRANDSEN OA, WAAGE J, LUNDER N, MØRK S, BERGE RK, JØRGENSEN HA, STEEN VM: Acute clozapine exposure in vivo induces lipid accumulation and marked sequential changes in the expression of SREBP, PPAR, and LXR target genes in rat liver. Psychopharmacology 203: 73-84, 2009. 
FORCHERON F, ABDALLAH P, BASSET A, DEL CARMINE P, HAFFAR G, BEYLOT M: Nonalcoholic hepatic steatosis in Zucker diabetic rats: spontaneous evolution and effects of metformin and fenofibrate. Obesity 17: 1381-1389, 2009.

FRANCO R, SCHONEVELD OJ, PAPPA A, PANAYIOTIDIS MI: The central role of glutathione in the pathophysiology of human diseases. Arch Physiol Biochem 113: 234-258, 2007.

GAO D, WEI C, CHEN L, HUANG J, YANG S, DIEHL AM: Oxidative DNA damage and DNA repair enzyme expression are inversely related in murine models of fatty liver disease. Am J Physiol 287: G1070-G1077, 2004.

GARCÍA-RUIZ I, RODRÍGUEZ-JUAN C, DÍAZ-SANJUAN T, DEL HOYO P, COLINA F, MUÑOZ-YAGÜE T, SOLÍS-HERRUZO JA: Uric acid and anti-TNF antibody improve mitochondrial dysfunction in ob/ob mice. Hepatology 44: 581-591, 2006.

GEORGE J, PERA N, PHUNG N, LECLERCQ I, YUN HOU J, FARRELL G: Lipid peroxidation, stellate cell activation and hepatic fibrogenesis in a rat model of chronic steatohepatitis. J Hepatol 39: 756-764, 2003.

GHOSHAL AK, FARBER E: Choline deficiency, lipotrope deficiency and the development of liver disease including liver cancer: a new perspective. Lab Invest 68: 255-260, 1993.

GRATTAGLIANO I, CARACENI P, CALAMITA G, FERRI D, GARGANO I, PALASCIANO G, PORTINCASA P: Severe liver steatosis correlates with nitrosative and oxidative stress in rats. Eur J Clin Invest 38: 523-530, 2008.

HEGARTY BD, COONEY GJ, KRAEGEN EW, FURLER SM: Increased efficiency of fatty acid uptake contributes to lipid accumulation in skeletal muscle of high fat-fed insulin-resistant rats. Diabetes 51: 1477-1484, 2002.

HISSIN PJ, HILF R: A fluorometric method for determination of oxidized and reduced glutathione in tissues. Anal Biochem 74: 214-226, 1976.

JEONG WI, JEONG DH, DO SH, KIM YK, PARK HY, KWON OD, KIM TH, JEONG KS: Mild hepatic fibrosis in cholesterol and sodium cholate diet-fed rats. J Vet Med Sci 67: 235-242, 2005.

KANĎÁR R, ŽÁKOVÁ P, LOTKOVÁ H, KUČERA O, ČERVINKOVÁ Z: Determination of reduced and oxidized glutathione in biological samples using liquid chromatography with fluorimetric detection. $J$ Pharm Biomed Anal 43: 1382-1387, 2007.

KAWASAKI T, IGARASHI K, KOEDA T, SUGIMOTO K, NAKAGAWA K, HAYASHI S, YAMAJI R, INUI H, FUKUSATO T, YAMANOUCHI T: Rats fed fructose-enriched diets have characteristics of nonalcoholic hepatic steatosis. J Nutr 139: 2067-2071, 2009.

KIRSCH R, CLARKSON V, VERDONK RC, MARAIS AD, SHEPHARD EG, RYFFEL B, DE LA M HALL P: Rodent nutritional model of steatohepatitis: effects of endotoxin (lipopolysaccharide) and tumor necrosis factor alpha deficiency. J Gastroenterol Hepatol 21: 174-182, 2006.

LEE GS, YAN JS, NG RK, KAKAR S, MAHER JJ: Polyunsaturated fat in the methionine-choline-deficient diet influences hepatic inflammation but not hepatocellular injury. J Lipid Res 48: 1885-1896, 2007.

LIEBER CS, LEO MA, MAK KM, XU Y, CAO Q, REN C, PONOMARENKO A, DECARLI LM: Model of nonalcoholic steatohepatitis. Am J Clin Nutr 79: 502-509, 2004.

LONDON RM, GEORGE J: Pathogenesis of NASH: animal models. Clin Liver Dis 11: 55-74, 2007.

LOWRY OH, ROSEBROUGH NJ, FARR AL, RANDALL RJ: Protein measurement with the Folin phenol reagent. J Biol Chem 193: 265-275, 1951.

MALAGUARNERA M, Di ROSA M, NICOLETTI F, MALAGUARNERA L: Molecular mechanisms involved in NAFLD progression. J Mol Med 87: 679-695, 2009.

MCCLAIN CJ, MOKSHAGUNDAM SP, BARVE SS, SONG Z, HILL DB, CHEN T, DEACIUC I: Mechanisms of non-alcoholic steatohepatitis. Alcohol 34: 67-79, 2004.

NANJI AA: Animal models of nonalcoholic fatty liver disease and steatohepatitis. Clin Liver Dis 8: 559-574, 2004.

PÉGORIER JP, LE MAY C, GIRARD J: Control of gene expression by fatty acids. J Nutr 134: 2444S-2449S, 2004.

PESSAYRE D: Role of mitochondria in non-alcoholic fatty liver disease. J Gastroenterol Hepatol 22 (Suppl): S20-S27, 2007. 
PILZ J, MEINEKE I, GLEITER CH: Measurement of free and bound malondialdehyde in plasma by high-performance liquid chromatography as the 2,4-dinitrophenylhydrazine derivative. J Chromatogr B Biomed Sci Appl 742: 315-325, 2000.

POPELOVÁ O, ŠTĚRBA M, ŠIMŮNEK T, MAZUROVÁ Y, GUNČOVÁ I, HROCH M, ADAMCOVÁ M, GERŠL V: Deferiprone does not protect against chronic anthracycline cardiotoxicity in vivo. J Pharmacol Exp Ther 326: 259-269, 2008.

REEVES PG, NIELSEN FH, FAHEY GC JR: AIN-93 purified diets for laboratory rodents: final report of the American Institute of Nutrition ad hoc writing committee on the reformulation of the AIN-76A rodent diet. $J$ Nutr 123: 1939-1951, 1993.

ROMESTAING C, PIQUET MA, BEDU E, ROULEAU V, DAUTRESME M, HOURMAND-OLLIVIER I, FILIPPI C, DUCHAMP C, SIBILLE B: Long term highly saturated fat diet does not induce NASH in Wistar rats. Nutr Metab (Lond) 4: 4, 2007.

ROMESTAING C, PIQUET MA, LETEXIER D, REY B, MOURIER A, SERVAIS S, BELOUZE M, ROULEAU V, DAUTRESME M, OLLIVIER I, FAVIER R, RIGOULET M, DUCHAMP C, SIBILLE B: Mitochondrial adaptations to steatohepatitis induced by a methionine- and choline-deficient diet. Am J Physiol 294: E110E119, 2008.

SATO N: Central role of mitochondria in metabolic regulation of liver pathophysiology. $J$ Gastroenterol Hepatol 22 (Suppl): S1-S6, 2007.

SCHNEIDER WC, HOGEBOOM GH: Intracellular distribution of enzymes. V. Further studies on the distribution of cytochrome c in rat liver homogenates. $J$ Biol Chem 183: 123-128, 1950.

SERVIDDIO G, BELLANTI F, TAMBORRA R, ROLLO T, CAPITANIO N, ROMANO AD, SASTRE J, VENDEMIALE G, ALTOMARE E: Uncoupling protein-2 (UCP2) induces mitochondrial proton leak and increases susceptibility of non-alcoholic steatohepatitis (NASH) liver to ischaemia-reperfusion injury. Gut 57: 957-965, 2008.

SVÁTKOVÁ R, ČERVINKOVÁ Z, KALOUS M, RAUCHOVÁ H, DRAHOTA Z: Respiratory control index of mitochondria isolated from regenerating rat liver. Physiol Res 45: 249-252, 1996.

TILG H: The role of cytokines in non-alcoholic fatty liver disease. Dig Dis 28: 179-185, 2010.

TURNER N, BRUCE CR, BEALE SM, HOEHN KL, SO T, ROLPH MS, COONEY GJ: Excess lipid availability increases mitochondrial fatty acid oxidative capacity in muscle: evidence against a role for reduced fatty acid oxidation in lipid-induced insulin resistance in rodents. Diabetes 56: 2085-2092, 2007.

VENDEMIALE G, GRATTAGLIANO I, CARACENI P, CARACCIO G, DOMENICALI M, DALL'AGATA M, TREVISANI F, GUERRIERI F, BERNARDI M, ALTOMARE E: Mitochondrial oxidative injury and energy metabolism alteration in rat fatty liver: effect of the nutritional status. Hepatology 33: 808-815, 2001.

YOSHIOKA S, HAMADA A, JOBU K, YOKOTA J, ONOGAWA M, KYOTANI S, MIYAMURA M, SAIBARA T, ONISHI S, NISHIOKA Y: Effects of Eriobotrya japonica seed extract on oxidative stress in rats with nonalcoholic steatohepatitis. J Pharm Pharmacol 62: 241-246, 2010.

ZHENG S, YUMEI F, CHEN A: De novo synthesis of glutathione is a prerequisite for curcumin to inhibit hepatic stellate cell (HSC) activation. Free Radic Biol Med 43: 444-453, 2007.

ZOU Y, LI J, LU C, WANG J, GE J, HUANG Y, ZHANG L, WANG Y: High-fat emulsion-induced rat model of nonalcoholic steatohepatitis. Life Sci 79: 1100-1107, 2006. 